\title{
PENGARUH TATA KELOLA PERUSAHAAN DAN KUALITAS AUDITOR TERHADAP MANAJEMEN LABA PADA BANK UMUM SYARIAH DI INDONESIA
}

\author{
Triana Novitasari ${ }^{1}$ \\ Email: triananovitasari24@yahoo.com \\ Nur Hisamuddin ${ }^{2}$ \\ Bunga Maharani ${ }^{3}$
}

\begin{abstract}
The aimed of this research was to examine the influence of corporate governance and auditor quality on earnings management in islamic banks in Indonesia. Corporate governance in this research used the size of audit committee, the size of Shariah Supervisory Board and managerial ownership as a proxy. Auditor quality in this research used accountant firm size as a proxy. The type of this research was explanatory research. The population were islamic banks listed in Bank Indonesia during 2013-2018. Using purposive sampling method, the sample were 60 islamic banks in Indonesia. Data resource using annual report from each islamic banks. The analysis method using multiple linear regression. The result indicated that managerial ownership had positive influence on earnings management, meanwhile the size of audit committee, the size of SSB, and auditor quality had no influence on earnings management.
\end{abstract}

Keywords: auditor quality, corporate governance, earnings management, islamic banks

\section{PENDAHULUAN}

Pelaporan keuangan merupakan kegiatan pengkomunikasian dan penyampaian informasi keuangan perusahaan kepada pengguna informasi. Hasil pelaporan keuangan yang paling menjadi perhatian adalah laporan keuangan. Laporan keuangan dibuat oleh manajemen dengan tujuan untuk menunjukkan hasil pertanggungjawaban terhadap sumber daya yang dipercayakan pemilik perusahaan

\footnotetext{
${ }^{1}$ Corresponding author: Jurusan Akuntansi, Fakultas Ekonomi dan Bisnis, Universitas Jember, Jalan Kalimantan No. 37, Kampus Tegalboto, Kecamatan Sumbersari, Jember, 68121, Jawa Timur, Indonesia.

2,3 Jurusan Akuntansi, Fakultas Ekonomi dan Bisnis, Universitas Jember, Jalan Kalimantan No. 37, Kampus Tegalboto, Kecamatan Sumbersari, Jember, 68121, Jawa Timur, Indonesia.
} 
kepadanya. Laporan tersebut disiapkan untuk menyampaikan informasi yang berkaitan dengan keuangan, kinerja, dan arus kas perusahaan (Kieso 2001).

Selain untuk pertanggungjawaban pihak manajemen, laporan keuangan juga digunakan sebagai salah satu sumber informasi pihak eksternal dalam menilai kinerja perusahaan. Informasi ini bermanfaat dalam pengambilan keputusan investasi dan kredit, serta berguna untuk memperkirakan cash flows masa depan.

Pentingnya informasi laba mendorong manajemen untuk memberikan perhatian lebih terhadap angka laba yang dilaporkan. Informasi laba sering menjadi target tindakan oportunis manajemen untuk memaksimalkan kesejahteraannya dengan cara memanipulasi tampilan laba sesuai keinginan. Tindakan oportunis ini dikenal dengan istilah manajemen laba (Setiawati dan Na'im 2000).

Manajemen laba merupakan upaya-upaya rekayasa dengan menggunakan teknik-teknik tertentu agar tampilan laporan keuangan terlihat lebih baik, terlihat lebih tinggi labanya, ataupun terlihat lebih rendah labanya. Rekayasa tampilan laporan keuangan disesuaikan dengan tujuan yang diharapkan manajemen, yaitu penurunan tarif pajak, penghindaran monopoli, kompensasi dan bonus, tekanan kovenan utang, maupun motivasi lainnya (Kustono 2013).

Pada umumnya, manajemen laba menurut (Kustono 2013) dapat dilakukan melalui dua cara. Pertama, dengan cara mengubah kebijakan-kebijakan akuntansi. Kedua, dengan mengendalikan akun-akun akrual, di mana akrual adalah perbedaan antara laba dan arus kas.

Lebih lanjut, akrual pada laporan keuangan seharusnya terpisah antara akrual diskresioner dan akrual nondiskresioner (Kustono 2013). Akrual diskresioner (discretionary accrual) adalah komponen akrual yang berada dalam kebijakan manajemen, sehingga manajer dapat memberi intervensi dalam proses pelaporan akuntansi, contohnya penentuan kebijakan pemberian kredit, kebijakan cadangan kerugian piutang, dan penilaian persediaan. Sebaliknya akrual nondiskresioner (nondiscretionary accrual) merupakan akrual yang tidak dapat dipengaruhi oleh kebijakan manajemen.

Tindakan manajemen laba dapat mengurangi kredibilitas laporan keuangan karena laporan tidak lagi menggambarkan keadaan perusahaan yang sebenarnya. Hal ini menambah bias dalam laporan keuangan sehingga dapat mengganggu pengguna laporan keuangan dalam mengambil keputusan. Para pengguna dapat keliru dalam membuat keputusan karena mereka berdasar pada angka akuntansi yang dimanipulasi (Soetedjo 2008).

Tindakan manajemen laba dapat diminimalisir melalui suatu mekanisme monitoring yang bertujuan untuk menyeimbangkan berbagai kepentingan dalam perusahaan, terutama kepentingan antara pihak manajer dengan pihak pemilik modal. Mekanisme ini disebut sebagai tata kelola perusahaan (corporate governance). Menurut Muhammad (2011), keberadaan tata kelola perusahaan dapat membangun seperangkat nilai, keyakinan, dan moral bagi pihak-pihak yang terlibat dalam suatu perusahaan.

Setiap sektor usaha harus menerapkan tata kelola perusahaan yang baik (Good Corporate Governance/GCG), tak terkecuali sektor perbankan. Sektor perbankan adalah sektor yang mempertemukan antara pihak yang membutuhkan dana dengan pihak yang kelebihan dana. Perputaran uang terjadi sangat cepat di dalamnya, sehingga mekanisme GCG diperlukan agar nilai kepercayaan tetap terbangun antara pihak-pihak yang terlibat. 
Sebagai negara dengan penduduk mayoritas beragama muslim, sektor perbankan berbasis syariah mulai tumbuh dan berkembang di Indonesia,. Keberadaan bank syariah mulai berkembang pesat dengan rata-rata pertumbuhan aset lebih dari $65 \%$ pertahun dalam lima tahun terakhir. Selain itu, diberlakukannya UU No.21 Tahun 2008 tentang Perbankan Syariah membuat pengembangan industri perbankan syariah nasional memiliki landasan hukum yang memadai dan akan mendorong pertumbuhannya lebih cepat lagi (www.bi.go.id).

Tidak jauh berbeda dengan bank konvensional, perbankan syariah merupakan lembaga intermediasi keuangan yang menghimpun dana dari masyarakat dalam bentuk simpanan dan menyalurkannya kepada masyarakat lain yang membutuhkan pembiayaan. Hal yang membedakan adalah bank syariah harus lebih dari sekadar lembaga yang cenderung mengutamakan keuntungan pribadi, tetapi juga harus menerapkan kaidah-kaidah moral dan tata nilai syariat Islam demi kebaikan dan kemaslahatan umat banyak (Mas'ud et al. 2020)

Proses GCG dalam perbankan syariah dapat dilihat sebagai mekanisme untuk menambah kepercayaan (trust), mengingat masyarakat membutuhkan kepercayaan dalam melakukan transaksi terutama yang berkaitan dengan dana atau pembiayaan. Kepercayaan (trust) sendiri merupakan interpretasi atas konsep amanah yang dalam syariah menunjukkan bahwa 'harta adalah milik Allah, dan manusia, secara individu atau kolektif adalah penjaganya,' (Muhammad 2011).

Mekanisme tata kelola perusahaan pada perbankan syariah di Indonesia telah diatur dalam Peraturan Bank Indonesia nomor 11/33/2009/PBI tentang Pelaksanaan Good Corporate Governance Bagi Bank Umum Syariah dan Unit Usaha Syariah. Secara umum, bank syariah memiliki mekanisme GCG yang sama dengan bank konvensional, yaitu terdiri atas Dewan Komisaris, Dewan Direksi, dan beberapa komite sebagai pihak eksternal yang membantu pengawasan direksi. Perbedaan hanya terletak pada adanya Dewan Pengawas Syariah (DPS), yang bertugas mengawasi kegiatan bank umum syariah agar sesuai dengan syariat-syariat Islam.

Barnhart dan Rosenstein dalam Indriani (2010:3) menjelaskan bahwa mekanisme GCG terdiri dari mekanisme internal dan mekanisme eksternal. Mekanisme internal meliputi struktur dewan direksi, kepemilikan manajerial dan kompensasi eksekutif, sedangkan mekanisme eksternal meliputi pasar untuk kontrol perusahaan, kepemilikan institusional, dan tingkat pendanaan dengan hutang (debt financing). Veronica dan Bachtiar (2006) memiliki penjabaran tersendiri mengenai mekanisme GCG, yang mana GCG dapat diwujudkan apabila terdapat dewan direksi, dewan komisaris, komite audit, kualitas audit dan kepemilikan institusional.

Terdapat beberapa penelitian tentang pelaksanaan GCG dan pengaruhnya terhadap manajemen laba. Hanifah (2017) menguji hubungan ukuran komite audit dan ukuran DPS terhadap kecenderungan manajer melakukan manajemen laba, dan hasilnya baik ukuran komite audit maupun ukuran DPS berpengaruh negatif dan signifikan terhadap manajemen laba. Hasil berbeda ditemukan Suryanto (2014) yang membuktikan bahwa ukuran komite audit tidak berpengaruh terhadap manajemen laba, dan di sisi lain ukuran DPS berpengaruh signifikan dalam membatasi manajemen laba.

Kepemilikan saham oleh pihak manajer dibatasi agar memperkecil kemungkinan manajer melakukan tindakan yang menguntungkan dirinya sendiri. Mekanisme ini kemudian disebut kepemilikan manajerial dan terdapat beberapa penelitian yang menguji pengaruh kepemilikan manajerial terhadap manajemen laba. 
Ujiyantho dan Pramuka (2007) dan Indriani (2010) membuktikan bahwa kepemilikan manajerial memiliki pengaruh positif dan signifikan terhadap manajemen laba. Artinya, semakin sedikit kepemilikan manajerial maka semakin kecil pula kemungkinan manajeman laba.

Menurut Watts dan Zimmerman (dalam Indriani, 2010), pemeriksaan laporan keuangan oleh kantor akuntan publik juga dapat digunakan sebagai monitoring tindakan manajemen yang oportunistik dalam melaporkan kinerja perusahaan. Amijaya (2013) dan Satrio et al. (2018) membuktikan bahwa ada keterkaitan antara manajemen laba dengan kualitas auditor. Manajemen laba yang terjadi pada perusahaan yang diaudit oleh auditor yang temasuk dalam KAP Big Four lebih rendah daripada perusahaan yang diaudit oleh KAP Non Big Four. Luhgiatno (2010) justru menemukan hasil yang berbeda, di mana tidak ditemukannya pengaruh kualitas audtor terhadap manajemen laba.

Berdasarkan latar belakang tersebut, terdapat empat rumusan masalah pada penelitian ini: (1) apakah ukuran komite audit berpengaruh terhadap berkurangnya praktik manajemen laba perbankan syariah di Indonesia, (2) apakah ukuran Dewan Pengawas Syariah berpengaruh terhadap praktik manajemen laba perbankan syariah di Indonesia, (3) apakah kepemilikan manajerial berpengaruh terhadap praktik manajemen laba perbankan syariah di Indonesia, dan (4) apakah kualitas auditor berpengaruh terhadap praktik manajemen laba perbankan syariah di Indonesia. Adapun tujuan dari penelitian ini untuk menguji apakah mekanisme tata kelola perusahaan dan kualitas auditor mampu membatasi perilaku manajemen laba di BUS.

\section{METODE PENELITIAN}

\subsection{Rancangan atau Desain Penelitian}

Jenis penelitian adalah eksplanatori, yaitu bertujuan untuk menguji keterkaitan antar beberapa variabel melalui pengujian hipotesis. Melalui penelitian eksplanatori, peneliti berusaha menguji dan menjelaskan pengaruh tata kelola perusahaan dan kualitas auditor terhadap manajemen laba, kemudian menganalisisnya sampai pada penarikan suatu kesimpulan. Penelitian bersifat kuantitatif dengan objek penelitian Bank Umum Syariah (BUS) yang terdaftar di Bank Indonesia periode 2013-2018. Data kuantitatif berupa laporan keuangan masing-masing BUS.

\subsection{Jenis dan Sumber Data}

Jenis data yang digunakan adalah data sekunder, yaitu laporan keuangan BUS periode 2013-2018. Laporan keuangan diperoleh dari situs resmi masing-masing BUS.

\subsection{Populasi dan Sampel}

Populasi penelitian adalah BUS yang terdaftar di Bank Indonesia periode 2013-2018. Teknik penentuan sampel adalah purposive sampling dan didapatkan 10 BUS yang menjadi sampel penelitian yaitu: Bank Muamalat Indonesia, Bank Syariah Mandiri, Bank Negara Indonesia Syariah, Bank Rakyat Indonesia, Bank Mega Syariah Indonesia, Bank Syariah Bukopin, Bank Victoria Syariah, Bank Maybank Syariah, Bank Panin Syariah, Bank Central Asia Syariah. Total sampel pada penelitian adalah 60 BUS.. 


\subsection{Metode Analisis Data}

Metode analisis data yang digunakan dalam penelitian ini adalah metode statistik dengan pendekatan kuantitatif, sehingga proses analisis datanya menggunakan penghitungan angka-angka yang kemudian digunakan untuk mengambil suatu kesimpulan. Analisis pada penelitian menggunakan regresi linier berganda., dengan menggunakan program SPSS (Statistical Product and Service Solution).

\section{HASIL DAN PEMBAHASAN}

\subsection{Gambaran Umum Objek Penelitian}

Terdapat 72 BUS yang terdaftar di BI selama periode 2013-2018. Kriteria yang digunakan untuk memilih sampel penelitian yaitu BUS yang melaporkan laporan tahunan dalam jangka waktu 2013 hingga 2018. Berdasarkan kriteria, terdapat 12 BUS yang tidak memenuhi kriteria sehingga jumlah BUS yang digunakan dalam penelitian ini adalah 60 BUS.

\section{Data Penelitian}

Tabel 1. Hasil Statistik Deskriprif

\begin{tabular}{|c|c|c|c|c|c|}
\hline & $N$ & Minimum & Maximum & Mean & Std. Deviation \\
\hline MNJ-LABA & 60 & $-0,35$ & 0,23 & $-0,0100$ & 0,09611 \\
\hline UKKA & 60 & 2,00 & 7,00 & 3,8833 & 1,27680 \\
\hline UKDPS & 60 & 2,00 & 3,00 & 2,3167 & 0,46910 \\
\hline KAP & 60 & 0,00 & 1,00 & 0,2000 & 0,40338 \\
\hline MANAJERIAL & 60 & 0,00 & 1,00 & 0,5667 & 0,49972 \\
\hline
\end{tabular}

Sumber : Output SPSS

Statistik deskriptif dapat memberikan gambaran tentang suatu data yang dilihat dari nilai minimum, maksimum, rata-rata (mean), dan standar deviasi yang dihasilkan dari variabel penelitian. Hasil analisis statistik deskriptif dengan menggunakan program SPSS digambarkan pada Tabel 1.

\section{Analisis Regresi Linear Berganda}

Analisis ini bertujuan mengetahui sejauh mana pengaruh variabel dependen terhadap variabel independen.

Tabel 2. Hasil Analisis Regresi Linear Berganda

\begin{tabular}{lccccc}
\hline \multirow{2}{*}{ Model } & \multicolumn{2}{c}{$\begin{array}{c}\text { Unstandardized } \\
\text { Coefficients }\end{array}$} & $\begin{array}{c}\text { Stand. } \\
\text { Coeff. }\end{array}$ & \multirow{2}{*}{$\boldsymbol{t}$} & \multirow{2}{*}{ Sig. } \\
\cline { 2 - 4 } & $\boldsymbol{B}$ & $\begin{array}{c}\text { Std. } \\
\text { Error }\end{array}$ & Beta & & \\
\hline (Constant) & $-0,146$ & 0,074 & & $-1,960$ & 0,055 \\
UKKA & $-0,009$ & 0,011 & $-0,118$ & $-0,776$ & 0,441 \\
UKDPS & 0,062 & 0,029 & 0,302 & 2,122 & 0,038 \\
MANAJERIA & 0,071 & 0,038 & 0,296 & 1,875 & 0,066 \\
L & 0,023 & 0,035 & 0,120 & 0,664 & 0,509 \\
KAP & & & & & \\
Sumber : Output SPSS & & & &
\end{tabular}

Berdasarkan Tabel 2, variabel dalam penelitian ini dapat dinyatakan dalam model sebagai berikut: 


$$
Y=-0,146-0,009 X_{1}+0,062 X_{2}+0,071 X_{3}+0,023 X_{4}
$$

Koefisien regresi $\mathrm{X}_{1}$ (ukuran komite audit) dari perhitungan linier berganda sebesar -0,009 dengan parameter negatif. Hal ini berarti setiap ada peningkatan ukuran komite audit sebesar satu satuan maka akan berdampak pada penurunan manajemen laba sebesar 0,009.

Koefisien regresi $\mathrm{X}_{2}$ (ukuran DPS) dari perhitungan linier berganda sebesar 0,062 dengan parameter positif. Hal ini berarti setiap ada peningkatan ukuran DPS sebesar satu satuan maka akan berdampak pada peningkatan manajemen laba sebesar 0,062 .

Koefisien regresi $\mathrm{X}_{3}$ (kepemilikan manajerial) dari perhitungan linier berganda sebesar 0,071 dengan parameter positif. Hal ini berarti setiap ada peningkatan kepemilikan manajerial sebesar satu satuan maka akan berdampak pada peningkatan manajemen laba sebesar 0,071.

Koefisien regresi $\mathrm{X}_{4}$ (kualitas auditor) dari perhitungan linier berganda sebesar 0,023 dengan parameter positif. Hal ini berarti setiap ada peningkatan kualitas auditor sebesar satu satuan maka akan berdampak pada peningkatan manajemen laba sebesar 0,023 .

\section{Uji t}

Uji t bertujuan untuk mengetahui hubungan signifikansi dari masing-masing variabel bebas terhadap variabel terikat. Dalam penelitian ini, uji t dilakukan untuk mengetahui lebih lanjut manakah di antara keempat variabel bebas yang berpengaruh signifikan terhadap manajemen laba. Hasil uji t ditunjukkan pada Tabel 3 berikut.

Tabel 3. Pengujian Hipotesis (Uji t)

\begin{tabular}{|c|c|c|c|c|c|c|}
\hline \multirow{2}{*}{ Model } & \multicolumn{2}{|c|}{$\begin{array}{c}\text { Unstandardize } \\
\text { d Coeff. }\end{array}$} & \multirow{2}{*}{$\begin{array}{c}\text { Stand. } \\
\text { Coeff. }\end{array}$} & \multirow{2}{*}{$t$} & \multirow{2}{*}{ Sig. } & \multirow{2}{*}{$\begin{array}{c}\text { Keputus- } \\
\text { an }\end{array}$} \\
\hline & $B$ & $\begin{array}{c}\text { Std. } \\
\text { Error }\end{array}$ & & & & \\
\hline (Const.) & $-0,146$ & 0,074 & & $-1,960$ & 0,055 & \\
\hline $\mathrm{X}_{1}$ & $-0,009$ & 0,011 & $-0,118$ & $-0,776$ & 0,441 & Ditolak \\
\hline $\mathrm{X}_{2}$ & 0,062 & 0,029 & 0,302 & 2,122 & 0,038 & Ditolak \\
\hline $\mathrm{X}_{3}$ & 0,071 & 0,038 & 0,296 & 1,875 & 0,066 & Diterima \\
\hline$X_{4}$ & 0,023 & 0,035 & 0,120 & 0,664 & 0,509 & Ditolak \\
\hline
\end{tabular}

Keterangan: pengujian hipotesis menggunakan uji $t$ satu arah, dimana signifikan pada tingkat kepercayaan $90 \%$.

Sumber : Output SPSS

Tabel 3 menunjukkan variabel ukuran komite audit $\left(\mathrm{X}_{1}\right)$ memiliki nilai koefisien regresi sebesar -0,009 dan nilai signifikansi sebesar 0,441. Nilai koefisien regresi menunjukkan hubungan yang negatif, sedangkan nilai signifikansi sebesar $0,441(>0,10)$ menunjukkan bahwa variabel komite audit tidak berpengaruh terhadap manajemen laba. Berdasarkan hal tersebut maka " $\mathrm{H}_{1}$ : ukuran komite audit berpengaruh terhadap manajemen laba" ditolak. .

Pada Tabel 3, variabel ukuran DPS $\left(\mathrm{X}_{2}\right)$ memiliki nilai koefisien regresi sebesar 0,062 dan nilai sig 0,038 . Nilai koefisien regresi menunjukkan hubungan yang positif. Nilai signifikansi $0,038(<0,10)$ menunjukkan bahwa variabel ukuran 
DPS berpengaruh terhadap manajemen laba pada tingkat kepercayaan $90 \%$, sehingga " $\mathrm{H}_{2}$ : ukuran DPS berpengaruh terhadap manajemen laba" diterima.

Berdasar Tabel 3, variabel kepemilikan manajerial $\left(\mathrm{X}_{3}\right)$ memiliki nilai koefisien regresi sebesar 0,071 dan nilai signifikansi 0,033. Nilai signifikansi sebesar $0,033(<0,015)$ menunjukkan bahwa variabel kepemilikan manajerial berpengaruh terhadap manajemen laba pada tingkat kepercayaan 90\%. Nilai koefisien regresi menunjukkan hubungan yang positif, sehingga " $\mathrm{H}_{3}$ : kepemilikan manajerial berpengaruh terhadap manajemen laba" diterima.

Tabel 3 menunjukkan variabel kualitas auditor $\left(\mathrm{X}_{4}\right)$ memiliki nilai koefisien regresi sebesar 0,023 dan nilai signifikansi 0,664. Nilai koefisien regresi menunjukkan hubungan yang positif, sedangkan nilai signifikansi sebesar 0,664 $(>0,05)$ menunjukkan bahwa variabel kualitas auditor tidak berpengaruh terhadap manajemen laba. Berdasarkan hal tersebut maka " $\mathrm{H}_{4}$ : kualitas auditor berpengaruh terhadap manajemen laba" ditolak.

\section{Pembahasan}

\subsection{Pengaruh Ukuran Komite Audit Terhadap Manajemen Laba}

Berdasarkan hasil penelitian, variabel ukuran komite audit tidak berpengaruh terhadap manajemen laba BUS, sehingga $\mathrm{H} 1$ ukuran komite audit berpengaruh terhadap manajemen laba ditolak. Arah koefisien negatif menunjukkan bahwa semakin besar ukuran komite audit, maka semakin kecil manajemen laba yang dilakukan BUS.

Ketidaksesuaian hasil penelitian dengan hipotesis karena adanya kemungkinan bahwa pembentukan komite audit dalam perusahaan didasari sebatas untuk memenuhi regulasi dari Peraturan Otoritas Jasa Keuangan Nomor 55/POJK.04/2015 Tentang Pembentukan dan Pedoman Pelaksanaan Kerja Komite Audit. Pada peraturan tersebut mensyaratkan perusahaan agar mempunyai komite audit yang paling sedikit terdiri dari seorang komisaris independen, seorang pihak independen yang memiliki keahlian di bidang keuangan atau akuntansi, dan seorang pihak independen yang memiliki keahlian di bidang hukum, sehingga dalam pelaksanaannya komite audit kurang efektif dalam menjalankan tugas dan tanggung jawabnya terhadap pengelolaan perusahaan.

Hasil penelitian mengenai pengaruh ukuran komite audit terhadap manajemen laba sama dengan hasil penelitian Hazri (2008), Suryanto (2014), Haryati dan Cahyati (2015), Nurjannah (2017), dan Purnamasari (2018) yang menyatakan bahwa ukuran komite audit tidak berpengaruh terhadap manajemen laba. Hal ini berarti ukuran komite audit belum mampu membatasi perilaku manajer BUS untuk melakukan manajemen laba.

\subsection{Pengaruh Ukuran Dewan Pengawas Syariah Terhadap Manajemen Laba}

Berdasarkan hasil pengujian, ditemukan bahwa variabel ukuran DPS berpengaruh terhadap manajemen laba, namun karena arah koefisien menunjukkan nilai positif maka $\mathrm{H} 2$ yang menyatakan bahwa ukuran DPS berpengaruh terhadap manajemen laba, ditolak.

Arah koefisien antara variabel DPS dan manajemen laba menunjukkan arah positif, artinya semakin besar ukuran DPS maka semakin tinggi manajemen laba yang dilakukan BUS. Dengan kata lain, semakin banyak anggota DPS yang dilibatkan dalam pengawasan, akan memperbesar praktik manajemen laba. Hal ini 
dapat terjadi kemungkinan karena pengawasan DPS sebatas pada kegiatan BUS agar sesuai syariat Islam, tidak sampai pada pengawasan perlakuan akun-akun akrual, di mana praktik manajemen laba terindikasi dapat terjadi.

Hasil penelitian ini sejalan dengan hasil penelitian Hamdi dan Zarai (2014), Mulyasari (2017) yang menyatakan bahwa ukuran DPS tidak berpengaruh terhadap manajemen laba. Hal ini menunjukkan bahwa ukuran DPS belum cukup efektif untuk mengurangi tindakan manajemen laba di BUS.

\subsection{Pengaruh Kepemilikan Manajerial Terhadap Manajemen Laba}

Berdasarkan hasil pengujian, variabel kepemilikan manajerial berpengaruh terhadap manajemen laba sehingga H3 diterima. Selain itu arah koefisien menunjukkan nilai positif, yang berarti semakin besar kepemilikan manajerial maka semakin besar pula potensi manajer melakukan manajemen laba.

Hal ini disebabkan kepemilikan manajerial seperti pembelian saham maupun penghadiahan saham kepada pihak manajerial seperti direksi dan karyawan dapat mengurangi independensi manajer dalam melaksanakan tugasnya. Dengan kata lain, tingkat kepemilikan manajerial tidak dapat meningkatkan pengawasan terhadap praktik manajemen laba sehingga praktik ini dapat dihilangkan atau semakin ditekan.

Hasil penelitian ini konsisten dengan penelitian Ujiyantho dan Pramuka (2007), Boediono (2005), Hazri (2008), Indriani (2010), Abdillah (2015), dan Pratiwi (2016) yang menyatakan bahwa kepemilikan manajerial berpengaruh terhadap manajemen laba. Hal ini berarti kepemilikan manajerial dapat memotivasi perilaku manajer BUS untuk melakukan manajemen laba.

\subsection{Pengaruh Kualitas Auditor Terhadap Manajemen Laba}

Berdasarkan hasil penelitian yang menguji pengaruh antara variabel kualitas auditor terhadap manajemen laba, ditemukan bahwa kualitas auditor tidak berpengaruh terhadap manajemen laba. Arah koefisien menunjukkan tanda positif yang mana tidak sesuai dengan hipotesis penelitian sehingga $\mathrm{H} 4$ ditolak.

Dalam penelitian ini, dari 10 BUS hanya 3 bank yang menggunakan KAP Non Big Four sedangkan 7 lainnya menggunakan KAP Big Four. Berdasarkan hasil tersebut dapat dilihat bahwa tidak ada perbedaan hasil audit yang terlalu jauh antara KAP Big Four dan KAP Non Big Four. Hal ini dikarenakan auditor eksternal baik dari KAP Big Four maupun KAP Non Big Four telah melaksanakan audit berdasarkan standar audit yang sama. Hal tersebut juga tercantum dalam laporan keuangan perusahaan dalam Laporan Audit Independen. Oleh karena itu, selama akuntan publik mematuhi kode etik profesi maka akan menghasilkan kualitas audit yang baik dan dapat membatasi perusahaan untuk melakukan manajemen laba.

Hasil penelitian ini konsisten dengan penelitian terdahulu yang dilakukan oleh Soegeng (2005), Luhgiatno (2010), dan Indriani (2010) yang menemukan tidak adanya pengaruh signifikan antara manajemen laba dengan kualitas auditor yang diukur berdasarkan ukuran KAP (KAP Big Four dan Non Big Four). BUS yang diaudit oleh KAP besar, dalam hal ini KAP Big Four, tidak terbukti mampu membatasi perilaku manajemen untuk melakukan manajemen laba. 


\section{KESIMPULAN}

Berdasarkan penelitian yang telah dilakukan, dapat diambil kesimpulan sebagai berikut:

a. Ukuran komite audit tidak berpengaruh terhadap manajemen laba. Hal ini menunjukkan bahwa jumlah anggota yang terlibat dalam komite audit belum mampu membatasi perilaku manajer BUS dalam praktik manajemen laba di BUS.

b. Ukuran DPS tidak berpengaruh terhadap manajemen laba. Hal ini menunjukkan bahwa jumlah anggota dalam susunan DPS belum cukup mampu membatasi perilaku manajer BUS dalam praktik manajemen laba.

c. Kepemilikan manajerial berpengaruh terhadap manajemen laba. Hal ini menunjukkan bahwa kepemilikan manajerial dapat meningkatkan motivasi manajer untuk melakukan manajemen laba, sehingga keberadaan kepemilikan manajerial dapat ditekan atau bahkan dihilangkan untuk mengurangi praktik manajemen laba di BUS.

d. Kualitas auditor tidak berpengaruh terhadap manajemen laba. Hal ini menunjukkan bahwa kualitas auditor, yang diproksikan dengan ukuran KAP (KAP Big Four), belum mampu membatasi perilaku manajer BUS dalam melakukan manajemen laba

\section{DAFTAR PUSTAKA}

Amijaya, M. D. 2013. Pengaruh Kualitas Audit Terhadap Manajemen Laba (Studi Empiris pada Perusahaan Perbankan yang Terdaftar di BEI Tahun 20082011). Skripsi. Semarang: Program Sarjana Fakultas Ekonomika dan Bisnis Universitas Diponegoro.

Hanifah, M. R. 2017. Pengaruh Struktur Corporate Governance Terhadap Manajemen Laba Pada Bank Umum Syariah di Indonesia. Skripsi. Semarang: Program Sarjana Fakultas Ekonomika dan Bisnis Universitas Diponegoro.

Indriani, Y. 2010. Pengaruh Kualitas Auditor, Corporate Governance, Leverage dan Kinerja Keuangan Terhadap Manajemen Laba (Studi Pada Perusahaan Perbankan yang Terdaftar di Bursa Efek Indonesia (BEI) Tahun 2006-2008). Skripsi. Semarang: Program Sarjana Fakultas Ekonomika dan Bisnis Universitas Diponegoro.

Kieso, D. E. 2001. Intermediate Accounting. Tenth Edition. Asia: John Wiley and Son Inc. Terjemahan oleh Emil Salim. 2002. Akuntansi Intermediate. Edisi Kesepuluh. Jakarta: Erlangga.

Kustono, A. S. 2013. Manajemen Laba. Jember: Al Qashwa.

Luhgiatno. 2010. Analisis Pengaruh Kualitas Audit Terhadap Manajemen Laba (Studi pada Perusahaan yang Melakukan IPO di Indonesia). Jurnal Akuntansi Riset Universitas Pendidikan Indonesia. 2 (1):319-334.

Mas'ud, I., E. Setiawan, dan N. C. Yuliarti. 2020. The Effect of Financing Trading, Profit Sharing, and Ijarah to Falah in Sharia Banks. Journal of Contemporary Information Technology, Management, and Accounting 1 (1):39-46.

Muhammad. 2011. Manajemen Bank Syariah. Edisi Revisi Kedua. Yogayakarta: Unit Penerbit dan Percetakan Sekolah Tinggi Ilmu Manajemen YKPN. 
Satrio, A., M. L. Oktaroza, dan P. Purnamasari. 2018. Pengaruh Kualitas Audit dan Komite Audit Terhadap Manajemen Laba (Studi Empiris pada Perusahaan Manufaktur Subsektor Farmasi yang Terdaftar di Bursa Efek Indonesia (BEI) Tahun 2012-2016). Prosiding Akuntansi Universitas Islam Bandung (1):396403.

Setiawati, L., dan A. Na'im. 2000. Manajemen Laba. Journal oF Indonesaia Economy adn Business 15 (4):424-441.

Soetedjo, S. 2008. Faktor-faktor yang Mempengaruhi Praktik Manajemen Laba (Earnings Management) pada Perusahaan Manufaktur yang Terdaftar di Bursa Efek Indonesia. Jurnal Akuntansi Universitas Jember 6 (2):23-35.

Suryanto, T. 2014. Manajemen Laba Pada Bank Syariah di Indonesia: Peran Komite Audit dan Dewan Pengawas Syariah. Jurnal Bisnis dan Ekonomi Kinerja 18 (1):90-100.

Ujiyantho, M. A., dan B. A. Pramuka. 2007. Mekanisme Corporate Governance, Manajemen Laba, dan Kinerja Keuangan (Studi Pada Perusahaan Go Publik Sektor Manufaktur). Simposium Nasional Akuntansi X. 26-28 Juli 2007. Universitas Hasanuddin Makassar:1-26.

Veronica, S., dan Y. S. Bachtiar. 2006. Pengaruh Struktur Kepemilikan, Ukuran Perusahaan, dan Praktek Corporate Governance terhadap Pengelolaan Laba (Earnings Management). Simposium Nasional Akuntansi VII. 2-3 Desember 2004.:57-69. 